\title{
Gastric duplication in infants
}

\section{V. Spakhi ${ }^{1}$, 0. V. Liaturynska ${ }^{1}$, M. 0. Makarova ${ }^{1}$, I. 0. Anikin ${ }^{1}$, A. H. Zaporozhchenko ${ }^{2}$}

\author{
${ }^{1}$ Zaporizhzhia State Medical University, Ukraine, ${ }^{2}$ Zaporizhzhia City Children's General Hospital No 5, Ukraine
}

Clinicians pay close attention to the questions related to the diagnosis and treatment tactics of stomach defects with its obstruction in view of their stable frequency and lack of consensus on these diseases development mechanisms. The insufficient individual experience of every clinician leads to the difficulties in early diagnostic and the most adequate surgical intervention choice, and so, high rates of mortality.

Purpose of the work. Improvement of the diagnostic and treatment tactic in infants with gastric duplication.

Materials and methods. Clinical experience of two cases of the newborn children treatment with rare variants of digestive tract developmental defects is presented. In one child it was a case of stomach cystic duplication; and the other had a cystic duplication of stomach and duodenum.

Results. There have been 5 cases of the stomach duplication treatment in the last 5 years in the Pediatric Surgery Clinic of Zaporizhzhia State Medical University. Two children were diagnosed with this pathology in neonatal period. Clinical analysis of these cases is described in the article. Both infants have undergone the early operative intervention. Type and extent of the operation depended on the peculiarities of localization, sizes, clinical signs of the defects and the general state of patients. The main stages and methods of medical-diagnostic process of such patients' management are presented.

Conclusions. The analysis shows that the efficacy of stomach obstruction rare forms diagnosis is achieved by usage of algorithms based on the staged modern diagnostic methods, taking into account their resolution and congenital anomaly type. In congenital stomach and duodenum duplication maximal informativness can be achieved using ultrasound and CT (or MRI) of the abdominal cavity. The most effective and non-invasive is ultrasound method by high-resolution devices. The discussed clinical cases are examples of early diagnosis of the stomach duplication and the right choice of active tactics for such children management that has made it possible to obtain a successful treatment outcome.

\section{Подвоєння шлунка в дітей}

\section{О. В. Спахі, О. В. Аятуринська, М. А. Макарова, І. О. Анікін, А. Г. Запорожченко}

Пильна увага клініцистів до питань, що пов'язані з діагностикою та тактикою лікування вад шлунка, котрі супроводжуються його непрохідністю, визначається зберіганням протягом багатьох років їх стабільної частоти у структурі вроджених аномалій травного каналу та відсутністю єдиних поглядів на причини й механізми розвитку цих захворювань. Недостатній особистий досвід кожного із клініцистів призводить до виникнення труднощів щодо ранньої діагностики, вибору адекватного хірургічного втручання в кожному випадку, а також до збереження високих показників летальності від цих захворювань до сьогодні.

Мета роботи - поліпшення лікувально-діагностичної тактики при подвоєнні шлунка в новонароджених.

Матеріали та методи. Наведено клінічний аналіз двох випадків лікування новонароджених дітей із рідкісними вадами розвитку травного тракту. В однієї дитини діагностували кістозне подвоєння шлунка, в іншої - кістозне подвоєння шлунка та дванадцятипалої кишки.

Результати. У клініці дитячої хірургії Запорізького державного медичного університету за останні 5 років здійснили лікування 5 випадків подвоєння шлунка. У двох дітей цей діагноз визначили в період новонародженості. У статті наведено клінічний аналіз цих випадків. Дітям виконали раннє оперативне втручання. Варіант та обсяг втручання залежав від особливостей локалізації, розмірів, клінічних проявів утворень і загального стану пацієнтів. Висвітлили основні етапи та методи лікувально-діагностичного процесу введення таких пацієнтів.

Висновки. Аналіз сучасного стану проблеми свідчить, що максимальна ефективність діагностики рідкісних видів вродженої шлункової непрохідності досягається з використанням алгоритмів, які засновані на поетапному застосуванні сучасних методів діагностики, враховуючи їхню роздільну здатність і вид вродженої аномалії. При вроджених дуплікаціях шлунка та дванадцятипалої кишки максимальна інфрормативність може бути досягнута з використанням Узд і КТ (або МРТ) органів черевної порожнини. Найефективнішим і неінвазивним методом є УзД за допомогою апаратів з високою роздільною здатністю. Клінічні випадки є прикладом ранньої діагностики подвоєнь шлунка та правильно обраної активної тактики ведення таких малюків, що дало можливість досяпти успішного результату лікування.

\section{УАвоение желудка у детей}

\section{О. В. Спахи, О. В. Аятуринская, М. А. Макарова, И. А. Аникин, А. Г. Запорожченко}

Пристальное внимание клиницистов к вопросам, связанным с диагностикой и тактикой лечения пороков развития желудка, сопровождающихся его непроходимостью, определяется сохранением в течение многих лет их стабильной частоты в структуре врожденных аномалий пищеварительного канала и отсутствием единых взглядов на причины и механизмы развития этой группы заболеваний. Недостаточный личный опыт каждого клинициста приводит к возникновению трудностей ранней диагностики, выбора адекватного хирургического вмешательства в каждом случае, а также к сохранению высоких показателей летальности при данных заболеваниях до сих пор.

Цель работы - улучшение лечебно-диагностической тактики при удвоении желудка у новорожденных.
Key words: congenital abnormalities, newborns, stomach, duodenum.

\section{Zaporozhye}

medical journal

2018; 20 (3), 443-447

DOI:

$10.14739 / 2310-1210$

2018.3.130516

E-mail:

olgalyat@gmail.com

Ключові слова: вроджені аномалії, новонароджений, шлунок, АванаАцятипала кишка.

Запорізький медичний журнал. - 2018. -

T. 20, № 3(108). -

C. 443-447 
Материалы и методы. Приведен клинический анализ двух случаев лечения новорожденных с редкими пороками развития пищеварительного тракта. У одного ребенка имело место кистозное удвоение желудка, у второго - кистозное удвоение желудка и двенадцатиперстной кишки.

Результаты. В клинике детской хирургии Запорожского государственного медицинского университета за последние 5 лет проведено лечение 5 случаев удвоения желудка. У двоих детей этот диагноз поставлен в период новорожденности. В статье описан клинический анализ этих случаев. Детям выполнено раннее оперативное вмешательство. Вариант и объем вмешательства зависел от особенностей локализации, размеров, клинических проявлений и общего состояния пациентов. Описаны основные этапы и методы лечебно-диагностического процесса при ведении таких пациентов.

Выводы. Анализ современного состояния проблемы свидетельствует, что максимальная эффективность диагностики редких видов врожденной непроходимости желудка достигается при использовании алгоритмов, основанных на поэтапном использовании современных методов диагностики с учетом их разрешающей способности и вида врожденной аномалии. При врожденных дупликациях желудка и двенадцатиперстной кишки максимальная информативность может быть достигнута при использовании УЗИ и КТ (или МРТ) органов брюшной полости. При этом наиболее эффективным и неинвазивным методом является УЗИ с помощью аппаратов с высокой разрешающей способностью. Приведенные клинические случаи - пример ранней диагностики удвоений желудка и правильно выбранной тактики ведения таких детей, что позволило получить успешный результат лечения.

\section{Introduction}

More than 100 years history of stomach congenital malformations in children study shows the careful examination of issue on the one hand and its extraordinary relevance today on the other hand. Clinicians pay close attention to the questions related to the diagnosis and treatment tactics of stomach defects with its obstruction in view of their stable frequency in the gastrointestinal tract congenital anomalies structure for many years, and lack of consensus on these diseases development mechanisms [1,5,7].

The matter is also that the stomach congenital pathology is rather rare in the structure of children abdominal cavity surgical diseases, and its congenital obstruction occurs even more rarely. So, the insufficient individual experience of every clinician leads to the difficulties in early diagnostic and the most adequate surgical intervention choice, and thus, high rates of mortality due to this pathology remain until now $[5,6]$.

The congenital stomach diseases accompanied by obstruction include atresia, membranes and duplicates. The gastric duplication was first described by W. Lyons in 1916. Atresia and membranes have a reported incidence of 1 in $50000-100000$ newborns, and gastric duplication counts for $3.8-7.0 \%$ of all digestive tract congenital obstructions. The literature mainly describes the individual cases of these diseases, which indicates the lack of clinical experience in diagnosis, the rational method of their treatment choice and to a certain extent determines the relevance of this issue $[1,8,11]$.

The absence of clear signs of illness even in the case of modern diagnostic methods use is determined. Therefore, it is often impossible to distinguish between manifestations of double stomach and other abdominal space-occupying processes, accompanied by the upper gastrointestinal obstruction phenomena of varying degrees. Ultimately, the timely detection of these developmental abnormalities and the determination of surgical indications, which finally define the diseases surgical approach, are important.

Differential diagnostics of stomach congenital obstruction rare variants is made, as in the case of the congenital hypertrophic pyloric stenosis, with all diseases of surgical and nonsurgical nature, accompanied by vomiting syndrome. The first include all types of congenital gastrointestinal obstruction and their complications, the second - birth craniocervical trauma, diseases that are accompanied by toxic-hypoxic lesions of the central nervous system, adrenal glands pathology $[2,10]$.

Analysis of indications for surgical treatment in patients with gastric duplication has revealed that the defect was diagnosed accurately before operation only in 25-39\% of patients. In the other $61-75 \%$ of cases the reasons for surgery were the suspicions of various abdominal and thoracic cavity pathologies $[3,8]$.

By the results of analysis based on the modern diagnostic methods capabilities, the diagnostic algorithm of the stomach congenital obstruction, which is caused by gastric duplication, is developed and introduced into practice (Fig. 1) [1,8,12].

In the diagnosis of gastric duplications the radiological method of examination is relevant up to now, although it does not always yield positive results. The most objective information can be obtained using ultrasound and MRI of the abdominal cavity methods to make accurate diagnosis of the gastric duplication coupled with the disease clinical picture.

Data obtained as a result of additional methods (ultrasound, FGDS, MRI) allow to determine the accurate localization and cystic formations origin, to diagnose the abdominal cavity pathological formation, to timely determine the indications for surgical intervention and to continue the diagnostic process and the final treatment tactics determination on the operating table $[8,11]$.

Duplications and cysts of the stomach and duodenum are combined with other gastrointestinal tract abnormalities, diaphragmatic hernia, congenital heart defects, ears, skull and chest deformities in 20-25\% [2,5,15].

For gastric duplications surgical correction their removal is used by a method of extracting without its inoculation or with an underlying wall of the stomach in cases of it is adherent tightly to other organs. In the case of large duplication sizes, some authors recommend to remove the partition between the main and the additional organ and to perform anastomosis between them with a common cavity formation. In some cases, the surgery is confined to an anastomosis between the additional stomach and the intestine $[4,8,9,13]$.

The results of rare congenital defects of stomach with obstruction treatment can not be considered satisfactory due to high lethality, which is $12.9-14.4 \%$ for the gastric duplication $[1,4,14]$. 


\section{Purpose of the work}

Improvement of the diagnostic and treatment tactic in infants with gastric duplication.

\section{Materials and methods}

Literature review and clinical experience of two cases of the newborn children treatment with rare variants of digestive tract developmental defects is presented. In one child it was a case of stomach cystic duplication; and the other had a cystic duplication of stomach and duodenum. The early operative intervention was performed in both infants. Type and extent of the operation depended on the peculiarities of localization, sizes, clinical signs of the defects and the general state of patients. The main stages and methods of medical-diagnostic process of such patients' management are presented.

\section{Results}

There have been 5 cases of the stomach duplication treatment in the last 5 years in the Pediatric Surgery Clinic of Zaporizhzhia State Medical University. Two children were diagnosed with this pathology in neonatal period. Clinical analysis of these cases is described.

Clinical case № 1

A boy from Mariupol city, case report form № 8868, was born with a birth weight of $4000 \mathrm{~g}$ and Apgar scores of 7-8. He passed meconium and was breastfeeding. On the second day of life child presented a vomiting of fermented milk.

Anamnesis: a child was born to a G3 mother, gestation course was complicated by acute respiratory infection at 10 weeks, proteinuria at 25 weeks; ultrasound of the fetus at 25 weeks of pregnancy revealed an abdominal mass.

The infant was delivered to the Clinic of Pediatric Surgery in Zaporizhzhia by sanitary aviation service with provisional diagnosis: "Congenital defect of gastrointestinal tract development. Abdominal cyst? Cyst of pancreatic head? Fetal infection, bilateral focal pneumonia. Perinatal central nervous system hypoxic lesion. Dysmetabolic cardiomyopathy".

The baby was under the care in Neonatal Pathology Department, where the symptoms got worse - vomiting increased in volume, general condition worsened to severe, body weight gain was absent. Turgor and elasticity of soft tissues were reduced. Large fontanel was $1.5 \times 1.5 \mathrm{~cm}$. In the lungs breathing was pure. Heart sounds were clear, rhythmic. The abdomen was symmetrically enlarged in size, soft and painless when palpating in all departments. The liver and spleen were not enlarged. Laboratory blood parameters were not significantly altered.

The additional methods of examination were performed. At the abdominal cavity plain radiography the intestinal pneumatic reduction and shadow in the right half of the abdominal cavity were revealed (Fig. 2). In ultrasound of the abdominal cavity the round-shaped cystic mass 7.0 to $7.5 \mathrm{~cm}$ in size was determined (Fig. 3). CT examination of the abdomen showed a right-sided round cystic mass measuring $8 \times 7 \mathrm{~cm}$ with a homogeneous content and a contour up to $0.3 \mathrm{~cm}$. The intestinal loops were displaced peripherally by the mass; homogeneously structured liver was $2 \mathrm{~cm}$ protruded below the costal margin; pancreas was homogeneous, with normal size and position. Kidneys and spleen were with inconspicuous findings (Fig. 4).

After the preoperative preparation in the Neonatal Anesthesiology and Intensive Care Department a surgical intervention (laparotomy) was performed. During the abdominal cavity revision an elastic cystic mass originating from the pyloric part of stomach and the lower part of duodenum was revealed. At a distance of up to $30 \mathrm{~cm}$ from the ileocecal angle on the antimesenteric border of the terminal ileum, the Meckel's diverticulum on a wide base without any evidence of inflammation was found. The cystic formation of the stomach and duodenum was removed, and gastroenteroanastomosis by Bilrot-1 has been performed. The Meckel's diverticlum resection has been performed and

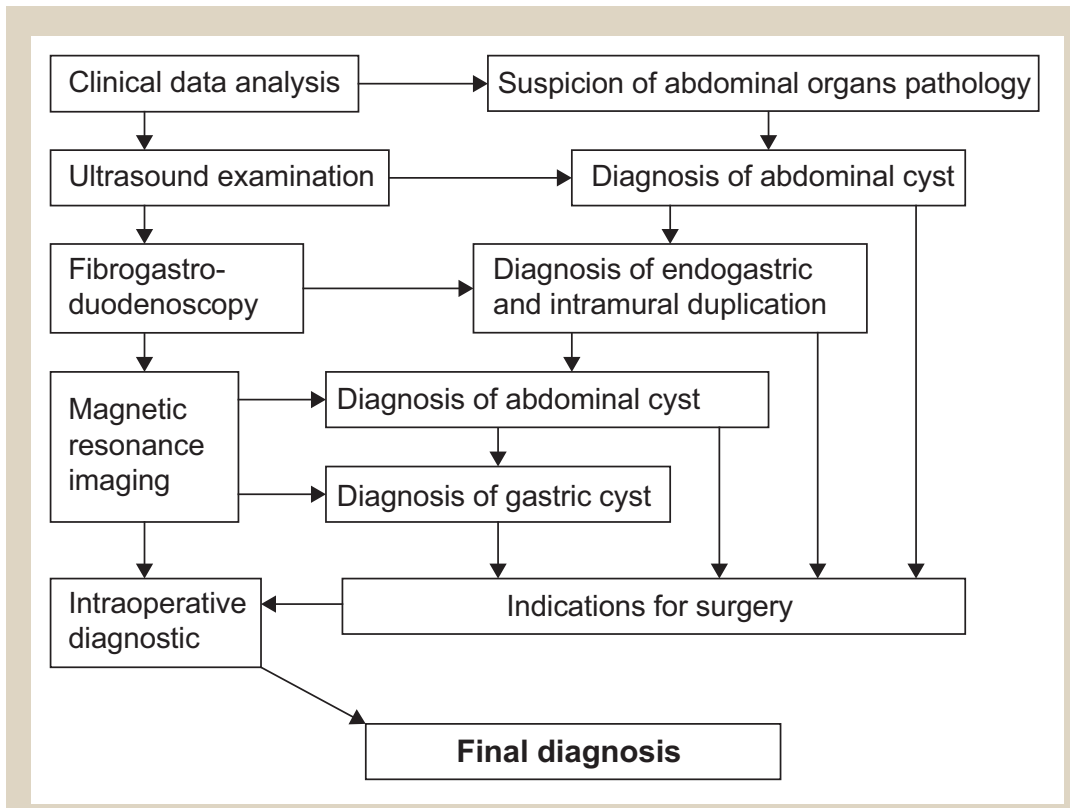

Fig. 1. The diagnostic algorithm of congenital stomach obstruction caused by gastric duplication.

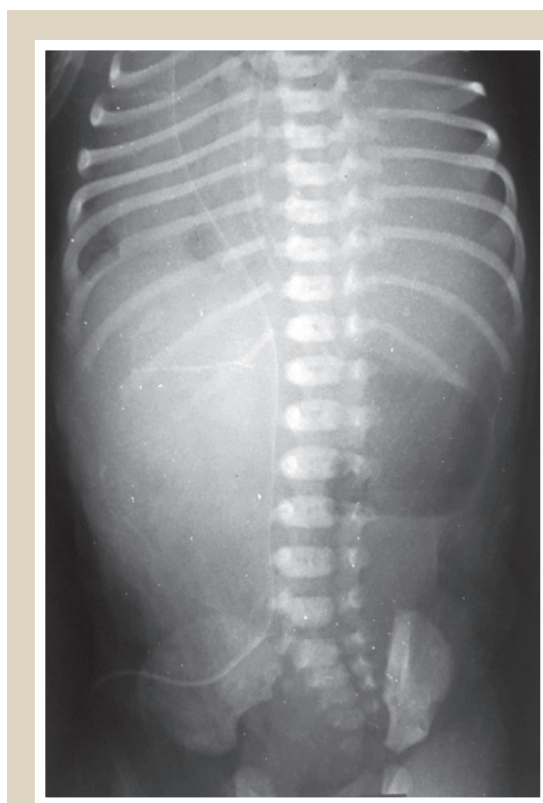

Fig. 2. Abdominal and chest radiography 


\section{Кминический случай}
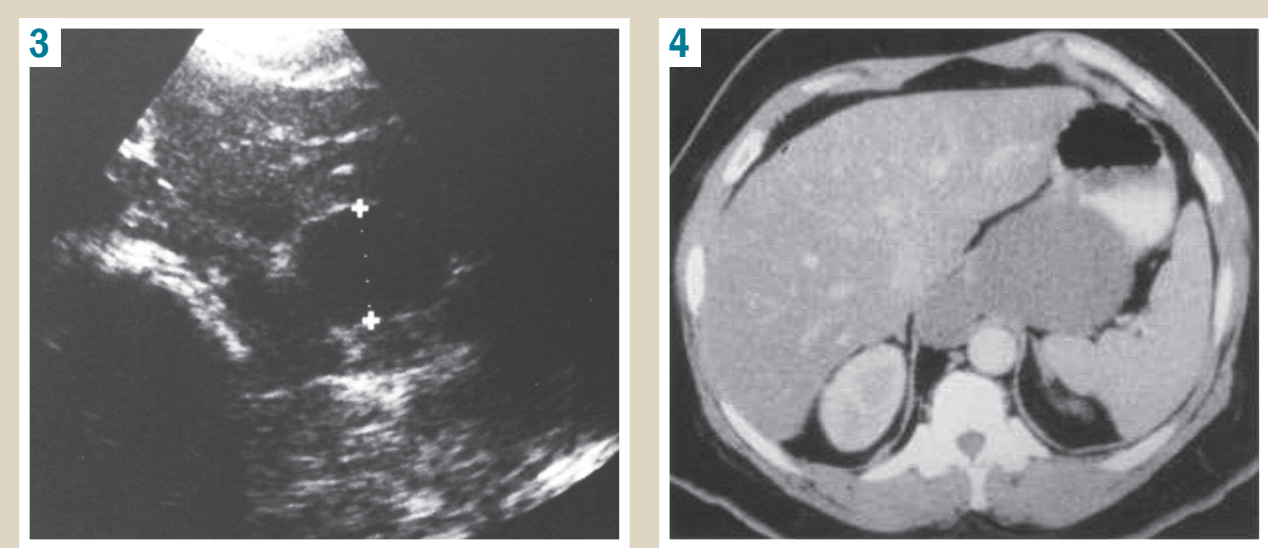

Fig. 3. Ultrasound picture of abdominal cyst.

Fig. 4. CT-diagnosis of the abdominal cyst.
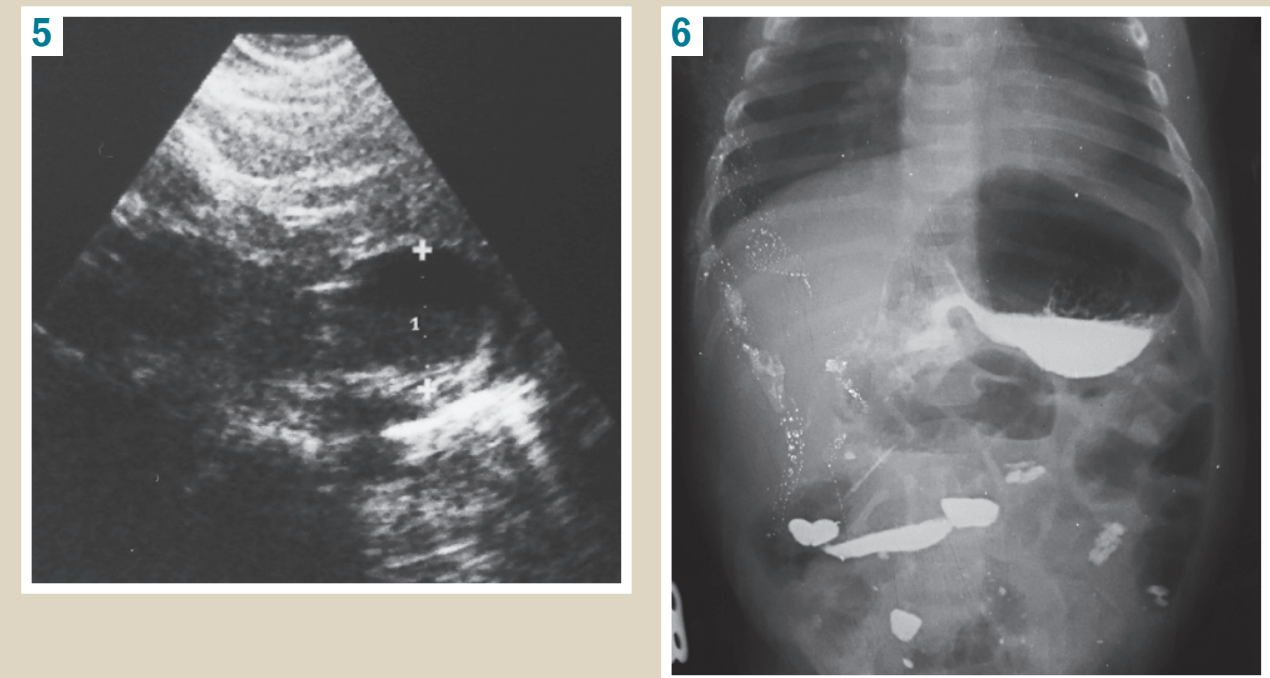

Fig. 5. Ultrasound picture

of abdominal cystic mass.

Fig. 6. X-ray signs of partial high intestinal obstruction.

the ileo-ileoanastomosis end-to-end accomplished. Histological examination confirmed the diagnosis of the stomach and duodenum cystic duplication.

Post-operative period was uneventful. Control ultrasound examination was performed in 10 days after surgery: volumetric formations in the abdominal cavity were not detected. The child was discharged from clinic on the 37 th day of life. Then he was examined in 4 months, there was no lag in physical development.

Clinical case № 2

An infant, case report form № 8868, was born at 39 week's gestation by an urgent Caesarean section for distress of the fetus with a birth weight of $2790 \mathrm{~g}$, and Apgar scores of 4-6 scores. A child was born to a G1P1 mother, who experienced threatened abortion at the $7^{\text {th }}$ gestation week. Abdominal ultrasound of the fetus at 22 weeks demonstrated a cystic formation in the abdominal cavity, atresia of the jejunum and enterogenous cysts.

Immediately after birth an infant was hospitalized in the Department of Anesthesiology and Intensive Care of Newborns with a diagnosis of cystic formation in the abdominal cavity. From the first day of the child's hospital stay (the first day of life) there were signs of the passage through gastrointestinal tract disorder. In particular, the enteral feeding was not absorbed, the gastric probe emptied fermented milk with mucus, that exceeded the enteral feeding volume, and there were signs of cholestasis: acholic stool, hyperbilirubinemia due to direct fraction, ALT elevation. The abdominal ultrasound was performed. It confirmed the results of pre-natal examination about the abdominal cystic formation (Fig. 5).

CT scan of abdominal organs also revealed the signs of cystic formation on the right side of abdomen. Considering the signs of partly violated passage through gastrointestinal tract, the results of ultrasound and CT examinations a surgical decision was made. But during the preoperative preparation (fluid management, antibiotic therapy, freshly frozen plasma transfusion) the condition of the child was improved, the signs of partial high intestinal obstruction gradually began to regress: the child began to assimilate the enteral feeding, a colored stool appeared. A case conference was held and as a result the operative intervention was decided to be postponed due to the positive dynamics to a stable state.

The child was transferred to the Pathology of Newborns Department in a state of moderate severity. But in few days, when trying to increase the enteral feeding volume to $60-70 \mathrm{ml}$, the signs of partial intestinal obstruction (passage through gastrointestinal tract violation) and cholestasis (acholic stool, total bilirubin was 138 and direct one $96 \mu \mathrm{mol} / \mathrm{l})$ began to increase again. X-ray barium contrast examination was performed and X-ray signs of partial high intestinal obstruction were revealed (Fig. 6).

Operative intervention was performed, which resulted 
in the retroperitoneal space cystic formation removal, which was located alongside the duodenum and caused mechanical compression of the intestine. Cystic formation was in capsule, isolated from surrounding tissues. Histological examination confirmed the cystic gastric duplication diagnosis.

The postoperative period was with edema syndrome, which regressed for three days in the adequate therapy course. Control ultrasound examination was performed 10 days after the operation: volumetric structures in the abdominal cavity were not detected. Clinical symptoms of intestinal obstruction were regressed. The child was discharged in satisfactory condition from the hospital. Examined after 2 months, the child condition was satisfactory without any complaints.

\section{Conclusions}

1. The analysis shows that the efficacy of stomach obstruction rare forms diagnosis is achieved by usage of algorithms based on the staged modern diagnostic methods, taking into account their resolution and congenital anomaly type.

2. In congenital stomach and duodenum duplication maximal informativness can be achieved using ultrasound and CT (or MRI) of the abdominal cavity. The most effective and non-invasive is ultrasound method by high-resolution devices.

3. The discussed clinical cases are examples of early diagnosis of the stomach duplication and the right choice of active tactics for such children management that has made it possible to obtain a successful treatment outcome.

Conflicts of Interest: authors have no conflict of interest to declare. Конфиікт інтересів: віАсутній.

\section{Information about authors:}

Spakhi O. V., MD, PhD, DSc, Professor, Head of the Department of Pediatric Surgery and Anestesiology, Zaporizhzhia State Medical University, Ukraine.

Liaturynska 0. V., MD, PhD, Associate Professor, Department of Pediatric Surgery and Anesthesiology, Zaporizhzhia State Medical University, Ukraine.

Makarova M. O, MD, PhD, Associate Professor, Department of Pediatric Surgery and Anesthesiology, Zaporizhzhia State Medical University, Ukraine.

Anikin I. O., MD, PhD, Associate Professor, Department of Pediatric Surgery and Anesthesiology, Zaporizhzhia State Medical University, Ukraine.

Zaporozhchenko A. H., MD, Chief Doctor, Zaporizhzhia City Children's General Hospital No 5, Ukraine.

\section{Відомості про авторів:}

Спахі О. В., А-р меА. наук, професор, зав. каф. Аитячої хірургії та анестезіології, Запорізький Аержавний медичний університет, Україна.

^ятуринська О. В., канд. меА. наук, Аоцент каф. Аитячої хірургії та анестезіології, Запорізький державний медичний університет, Україна.

Макарова М. О., канА. меА. наук, Аоцент каф. Аитячої хірургії та анестезіології, Запорізький державний меАичний університет, Україна.

Анікін І. О., канд. меА. наук, Аоцент каф. Аитячої хірургії та анестезіології, Запорізький державний медичний університет, україна.

Запорожченко А. Г., головний лікар Запорізької міської дитячої багатопрофільної мікарні № 5, Україна.
Сведения об авторах:

Спахи О. В., А-р меА. наук., профессор, зав. каф. Аетской хирургии и анестезиологии, Запорожский государственный медицинский университет, Украина.

Аятуринская О. В., канА. меА. наук., Аоцент каф. Аетской хирургии и анестезиологии, Запорожский государственный медицинский университет, Украина. Макарова М. А., канА. меА. наук, Аоцент каф. Аетской хирургии и анестезиологии Запорожский государственный меАицинский университет, Украина.

Аникин И. А., канА. меА. наук., Аоцент каф. Аетской хирургии и анестезиологии, Запорожский государственный меАицинский университет, Украина.

Запорожченко А. Г., главный врач Запорожской городской Аетской многопрофильной больницы № 5, Украина.

НаАійшла Ао реАакції / Received: 07.03.2018

Після Аоопрацювання / Revised: 16.03.2018

Прийнято Ао Аруку / Accepted: 19.03.2018

\section{References}

[1] Ashkraft, K. U., \& Kholder, T. M. (1997). Detskaya khirurgiya [Pediatric surgery]. (Vol. 2), (P. 100-104). Saint Petersburg. [in Russian].

[2] Bajrov, G. A. (1968). Khirurgicheskie poroki razvitiya u detej [Surgical defects of development in children]. Leningrad. [in Russian].

[3] Zhurilo, I. P., Fomenko, S. A., Litovka, V. K., Perunskij, V. P., Lepikhov, P. A., Gun'kin, A. Yu. (2001). Redkie varianty udvoeniya pishchevaritel'nogo tracta u detej [Rare variants of the digestive tract doubling in children]. Vestnik neotlozhnoj i vosstanovitel'noj mediciny, 2, 177-182 [in Russian].

[4] Grigovich, I. N. (1985). Redkie khirurgicheskie zabolevaniya pishchevaritel'nogo tracta [Rare surgical diseases of the digestive tract]. Leningrad [in Russian].

[5] Ishimov, Sh. S. (2012). O modifikacii operacii pri kistoznom udvoenii dvenadcatiperstnoj kishki [On the modification of the operation for the treatment of doudenal duplication cyst]. Detskaya khirurgiia, 6 , 56. [in Russian].

[6] Nechaev, V. N., Cherenkov, Yu. V. (2007) Diagnostika, profilaktika i terapiya vrozhdennykh anomalij razvitiya [Diagnostics, prevention and therapy of congenital anomalies of development]. Sovremennye tekhnologii v pediatrii i detskoj khirurgii. Proceedings of the 6th Russian Congress. (P. 132-133). Moscow. [in Russian].

[7] Sermyagin,V., Yurchuk, V., \& Lushina, N. (2007) Sdvigi sistemy gomeostaza u novorozhdennykh s vrozhdennymi porokami razvitiya zheludochno-kishechnogo trakta [Shifts of the homeostasis system in newborns with congenital malformations of the gastrointestinal tract]. Sovremennye tekhnologii v pediatrii i detskoj khirurgii. Proceedings of the 6th Russian Congress. (P. 301-302). Moscow. [in Russian].

[8] Spakhi, O. V. (2008). Diahnostyka ta khirurhichne likuvannia vrodzhenoi neprokhidnosti shlunku u ditei (Avtoref. dis... dokt. med. nauk) [Diagnosis and surgical treatment of congenital obstruction of the stomach in children. Dr. med. sci. diss.]. Kyiv. [in Ukrainian].

[9] You, H., Park, S., Kim, J., Lee H., Jang, S., Kim, G., \& Song, G. (2012). A Case of Duodenal Duplication Cyst Manifested by Duodenal Polyp. Clin Endosc, 45(4), 425-7. doi: 10.5946/ce.2012.45.4.425.

[10] Wolters, V. M., Nikkels, P. G., Van Der Zee, D. C., Kramer, P. P., De Schryver, J. E., Reijnen, I. G., \& Houwen, R. H. (2001). A gastric diverticulum containing pancreatic tissue and presenting a scongenital double pylorus: case report and review of the literature. J. Pediatr. Gastroenterol. Nutr. 33(1), 89-91. doi: 10.1097/00005176-200107000-00017.

[11] Le Stradic, C., Aroulandom, J., Kotobi, H., Pariente, D., Gaboran, C., Lemale, J., et al. (2016). Duodenal duplication revealed by acute pancreatitis. Arch Pediatr, 23(10), 1063-1066. doi: 10.1016/j.arcped.2016.06.015.

[12] Daher, P., Karam, L., \& Riachy, E. (2008). Prenatal diagnosis of an intrathoracic gastric duplication: a case report. J. Pediatr. Surg, 43(7), 1401-1404. doi: 10.1016/j.jpedsurg.2008.03.046.

[13] Jiang, W., Zhang, B., Fu, Y., Wang, J., Gao, S., Zhang, S., \& Wu, Y. L. (2011). Gastric duplication cyst lined by pseudostratified columnar ciliated epithelium: a case report and Literature review. J Zhejiang Univ SciB, 12, 28-31. doi: 10.1631/jzus.B1000130.

[14] Okamoto, T., Takamizawa, S., Yokoi, A., Satoh, Sh., \& Nishijima, E. (2008). Completely isolated alimentary tract duplication in neonate. Pediatr. Surg, 24(10), 1145-1147. doi: 10.1007/s00383008-2220-y.

[15] Singh, T., Rajdeo, H., Bhuta, K., \& Savino, J. A. (2013). Gastric Duplication Cyst: Two Case Reports and Review of the Literature. Case Rep Surg., 2013, 605059. doi: 10.1155/2013/605059. 